\title{
PENGARUH KOMPETENSI SISWA DAN PERAN SERTA BKK TERHADAP MOTIVASI UNTUK BEKERJA DI BIDANG OTOMOTIF SISWA KELAS XI JURUSAN TEKNIK KENDARAAN RINGAN SMK SE-KABUPATEN BANTUL
}

\author{
Muhammad Afifi \& Sukaswanto \\ Fakultas Teknik, Universitas Negeri Yogyakarta \\ Email: brianpradana08@yahoo.com
}

\begin{abstract}
This study aims to determine: (1) the effect of student competence on the motivation of students of class XI in the Department of Light Vehicle Engineering Vocational Schools in Bantul Regency, and (2) the influence of the participation of BKK on motivation to work in automotive in class XI students of the Department of Light Vehicle Engineering Vocational Schools in Bantul Regency. This research is a comparative associative research. The sampling technique uses proportional random sampling technique. The research sample was 92 students of class XI in Bantul Regency, Department of Light Vehicle Engineering, as many as 92 students. Data collection techniques using tests and questionnaires. The data analysis technique used the Independent $t$ Test. The results of the study showed that (1) Students with high competence had higher motivation to work in the automotive field than students who had low competence as indicated by the tcount greater than the ttable value $(6.209>1.973)$, the significance value is smaller than 0.05 (0,000 <0.05); and (2) Schools whose BKK participation is active have students with motivation to work in the automotive field higher than students whose BKK participation is less active as indicated by the tcount greater than the ttable value (6,510>1,973), the significance value is smaller of $0.05(0.006<0.05)$.
\end{abstract}

Keywords: Student Competence, Motivation, Special Job Fairs

\begin{abstract}
Abstrak
Penelitian ini bertujuan untuk mengetahui: (1) pengaruh kompetensi siswa terhadap motivasi siswa kelas XI Jurusan Teknik Kendaraan Ringan SMK se-Kabupaten Bantul, dan (2) pengaruh peran serta BKK terhadap motivasi untuk bekerja di bidang otomotif siswa kelas XI Jurusan Teknik Kendaraan Ringan SMK se-Kabupaten Bantul. Penelitian ini merupakan penelitian asosiatif komparatif. Teknik pengambilan sampel menggunakan teknik proporsional random sampling. Sampel penelitian adalah siswa kelas XI SMK se-Kabupaten Bantul Jurusan Teknik Kendaraan Ringan sebanyak 92 siswa. Teknik pengumpulan data menggunakan tes dan kuesioner. Teknik analisis data menggunakan uji Independent $t$ Test. Hasil penelitian menunjukkan bahwa (1) Siswa dengan kompetensi tinggi mempunyai motivasi untuk bekerja di bidang otomotif lebih tinggi dari pada siswa yang mempunyai kompetensi rendah yang ditunjukkan dari nilai $t_{\text {hitung }}$ lebih besar dari nilai $t_{\text {tabel }}(6,209>1,973)$, nilai signifikansi lebih kecil dari $0,05(0,000<0,05)$; dan (2) Sekolah yang peran serta BKKnya aktif mempunyai siswa dengan motivasi untuk bekerja di bidang otomotif lebih tinggi dari pada siswa yang peran serta BKKnya kurang aktif yang ditunjukkan dari nilai $t_{\text {hitung }}$ lebih besar dari nilai $t_{\text {tabel }}(6,510>1,973)$, nilai signifikansi lebih kecil dari $0,05(0,006<0,05)$.
\end{abstract}

Kata kunci: Kompetensi Siswa, Motivasi, Bursa Kerja Khusus 


\section{PENDAHULUAN}

Sekolah Menengah Kejuruan (SMK) adalah salah satu bagian dari pendidikan formal yang dirancang untuk dapat menghasilkan lulusan pada jenjang menengah yang direncanakan memiliki kemampuan dan keterampilan yang siap kerja sesuai dengan minat dan bakatnya masing-masing. Menurut Undang-Undang Sistem Pendidikan Nasional Nomor 20 Tahun 2003 bahwasanya "Pendidikan Kejuruan merupakan pendidikan menengah yang mempersiapkan peserta didik terutama untuk bekerja dalam bidang tertentu". Peraturan Pemerintah Nomor 29 Tahun 1990 dalam Bab (I) Pasal (1) Ayat (3) menyatakan bahwa "Pendidikan Menengah Kejuruan adalah pendidikan pada jenjang menengah yang mengutamakan pengembangan kemampuan siswa untuk melaksanakan jenis pekerjaan tertentu".

SMK di Kabupaten Bantul yang berusaha agar lulusannya dapat langsung terjun ke dunia kerja. Oleh karena itu, pendidikan pada SMK lebih ditekankan pada ilmu terapan di dunia kerja, seperti mekanik otomotif, kelistrikan, tata busana, serta boga. Salah satu bidang jurusan yang banyak diminati SMK di Kabupaten Bantul adalah otomotif. Siswa dilatih untuk mengenal seluk-beluk, kerusakan, dan perbaikan sepeda motor dan mobil. Bidang otomotif menggunakan banyak alat bantu seperti tang, mistar ukur, kunci pas, dan sebagainya. Banyaknya peralatan ini terkadang menyebabkan lamanya waktu pengajaran yang dibutuhkan, sementara jumlah pertemuan sangat dibatasi dan masih banyak bagian lain yang harus diajarkan (Akbar Suryanti, 2016: 3).

Pendidikan menengah kejuruan menyediakan suatu program keahlian khusus bagi para siswa untuk dapat langsung terjun langsung ke dunia kerja sesuai dengan kebutuhan yang dibutuhkan pada dunia usaha dan dunia industri (DU/DI). Tujuan Sekolah Menengah Kejuruan (SMK) adalah menyiapkan siswa produktif yang memiliki kompetensi dan keahlian sehingga siswa dapat bersaing di dunia usaha dan dunia industri (DU/DI). Para siswa di SMK diajarkan dan diberikan pengalaman-pengalaman mengenai suatu keahlian yang nantinya akan digunakan sesuai tuntutan yang dibutuhkan pada dunia usaha dan dunia industri (DU/DI). Pembekalan keahlian tersebut diharapkan akan mampu menghasilkan siswa-siswa yang produktif agar dapat bersaing dan memiliki keahlian di dunia usaha dan dunia industri (DU/DI) (Haryana, Tawardjono, \& Tafakur, 2018)

Saat ini, lulusan Sekolah Menengah Kejuruan (SMK) belum dapat terserap langsung oleh dunia usaha dan dunia industri (DU/DI). Kondisi tersebut tentunya bukan menjadi hal yang menggembirakan bagi dunia pendidikan. Pasalnya semakin banyak lulusan SMK saat ini hanya mampu menyumbang sumber daya manusia (SDM) dalam mengisi kebutuhan angkatan kerja yang ada. Keberadaan jumlah pengangguran Sekolah Menengah Kejuruan (SMK) dapat 
disebabkan oleh berbagai hal diantaranya karena minimnya lapangan pekerjaan yang tersedia dan sekolah dianggap kurang dapat memasarkan lulusannya untuk memasuki dunia usaha dan dunia industri (DU/DI). Kurangnya sekolah dalam membangun kemitraan dan mempromosikan lulusannya ke dunia usaha dan industri (DU/DI), padahal dunia usaha dan industri (DU/DI) mempunyai peranan yang penting dalam upaya penyerapan tenaga kerja dan angkatan kerja. Sekolah Menengah Kejuruan (SMK) mempunyai usaha untuk dapat mewujudkan keberhasilan tamatannya adalah dengan membangun kemitraan dengan pihak dunia usaha dan industri (DU/DI), ini dapat membantu para lulusan dalam mencari pekerjaan sesuai dengan kompetensinya. Salah satunya dapat menjalin kemitraan dengan Bursa Kerja Khusus (BKK).

Bursa kerja khusus (BKK) merupakan lembaga yang menjalankan fungsi penempatan untuk mempertemukan antara pencari kerja dan pengguna tenaga kerja yang terdapat di Satuan Pendidikan Menengah, di Satuan Pendidikan Tinggi dan di Lembaga Pelatihan Kerja (Depnakertrans RI, 2004, p.4). Bursa Kerja Khusus (BKK) adalah suatu unit di Satuan Pendidikan Menengah, di Satuan Pendidikan Tinggi dan di Lembaga Pelatihan Kerja sebagai wadah mempertemukan antara pencari kerja dengan pengguna tenaga kerja. Kegiatan BKK meliputi pemberian informasi seputar pasar kerja, pendaftaran pencari kerja, memberikan penyuluhan dan bimbingan jabatan, penyaluran dan penempatan tenaga kerja. BKK mempunyai fungsi untuk menjalin kerjasama dengan para stakeholder khususnya Dunia Usaha dan Dunia Industri (DU/DI) perihal penyerapan tenaga kerja sehingga mampu mengurangi angka pengangguran.

Hasil observasi yang dilakukan peneliti di sekolah pada tanggal 11 Januari 2018 diketahui bahwa benar apabila jumlah lulusan SMK otomotif saat ini tidak sebanding dengan tersedianya lapangan pekerjaan yang ada. Hasil informasi dari beberapa BKK sekolah diketahui jika tidak semua lulusan SMK otomotif memenuhi kriteria yang dibutuhkan oleh para pengguna tenaga kerja. Berdasarkan hasil observasi yang dilakukan peneliti tersebut pihak BKK menyatakan jika seringnya kriteria secara administrasi terpenuhi oleh lulusan SMK namun tidak sesuai dengan kebutuhan dunia usaha dan dunia industri. Artinya, siswa lulusan SMK tersebut hanya memiliki nilai kelulusan tanpa diimbangi oleh kompetensi sesuai dengan jurusan kelulusannya.

Kompetensi pada hakekatnya menunjukkan kecakapan seperti kecerdasan yang dimiliki oleh seseorang untuk menyelesaikan pekerjaan yang dibebankan kepadanya. Pentingnya kompetensi pencari kerja bagi pihak pengguna tenaga kerja karena nantinya diharapkan dapat meningkatkan kinerja pihak perusahaan. Setiap pihak pencari kerja pasti mempunyai suatu tujuan dan untuk mencapai tujuan tersebut, diperlukan pelaksanaan tugas yang efektif dari para calon pegawai. Pencapaian tujuan itu sendiri merupakan suatu sasaran yang dikehendaki dan sudah ditetapkan sebelumnya. Kompetensi kerja yang tinggi, seorang pencari kerja akan 


\section{Muhammad Afifi}

mampu berbuat banyak bagi pihak pengguna tenaga kerja, sebaliknya dengan kompetensi yang rendah seorang pencari kerja tidak akan dapat menyelesaikan tugasnya dengan sebaik-baiknya, yang akhirnya akan menghambat pencapaian tujuan perusahaan.

Sebagai pihak penyalur tenaga kerja, menghadapi kondisi tersebut tentunya pihak BKK tidak membiarkan begitu saja. Hasil observasi menemukan bahwa langkah strategis yang dilakukan pihak BKK supaya tidak mengecewakan pihak pengguna tenaga kerja adalah dengan melakukan training dan pelatihan-pelatihan disesuaikan dengan kualifikasi yang di butuhkan perusahaan, meskipun terkadang para pencari kerja tersebut masih belum memenuhi kualifikasi yang dibutuhkan. Hal ini dilakukan untuk mengoptimalkan proses perekrutan supaya dapat efektif dan efisien.

Penelitian ini bertujuan untuk mengetahui: (1) pengaruh kompetensi siswa terhadap motivasi siswa kelas XI Jurusan Teknik Kendaraan Ringan SMK se-Kabupaten Bantul, dan (2) pengaruh peran serta BKK terhadap motivasi untuk bekerja di bidang otomotif siswa kelas XI Jurusan Teknik Kendaraan Ringan SMK se-Kabupaten Bantul.

\section{METODE}

Penelitian ini termasuk ke dalam penelitian asosiatif komparatif. Penelitian asosiatif kausal adalah penelitian yang bertujuan untuk mengertahui pengaruh antara dua variabel atau lebih (Umar, 2005: 30). Penelitian komparatif adalah penelitian yang akan membandingkan dua variabel.

Penelitian ini dilakukan di SMK se-Kabupaten Bantul Jurusan Teknik Kendaraan Ringan yang meliputi SMK Muhammadiyah 1 Imogiri, SMK Muhammadiyah Bambanglipuro, SMKN Sedayu dan SMK Ma'arif Piyungan. Penelitian ini dilaksanakan pada bulan Januari 2019 sampai selesai.

Populasi penelitian adalah seluruh siswa kelas XI SMK se-Kabupaten Bantul Jurusan Teknik Kendaraan Ringan sebanyak 122 siswa yang meliputi SMK Muhammadiyah 1 Imogiri, SMK Muhammadiyah Bambanglipuro, SMKN Sedayu dan SMK Ma'arif Piyungan. Teknik pengambilan sampel menggunakan teknik proporsional random sampling dengan menggunakan tabel Krecjie dan Morgan pada taraf signifikan 5\%. Sampel penelitian adalah siswa kelas XI SMK se-Kabupaten Bantul Jurusan Teknik Kendaraan Ringan sebanyak 92 siswa.

Teknik pengumpulan data menggunakan tes dan kuesioner. Teknik analisis data menggunakan uji Independent $t$ Test. 


\section{HASIL DAN PEMBAHASAN}

\section{Hasil Penelitian}

\section{Kompetensi Siswa}

Berdasarkan hasil penelitian diketahui bahwa kompetensi siswa berada pada kategori tinggi sebanyak 44 siswa $(47,83 \%)$, dan berada pada kategori rendah sebanyak 48 siswa $(52,17 \%)$. Dengan demikian dapat disimpulkan bahwa kecenderungan kompetensi siswa kelas XI Jurusan Teknik Kendaraan Ringan SMK se-Kabupaten Bantul berada pada kategori rendah sebanyak 48 siswa $(52,17 \%)$. Adapun penggambarannya dapat digambarkan pada gambar di bawah ini.

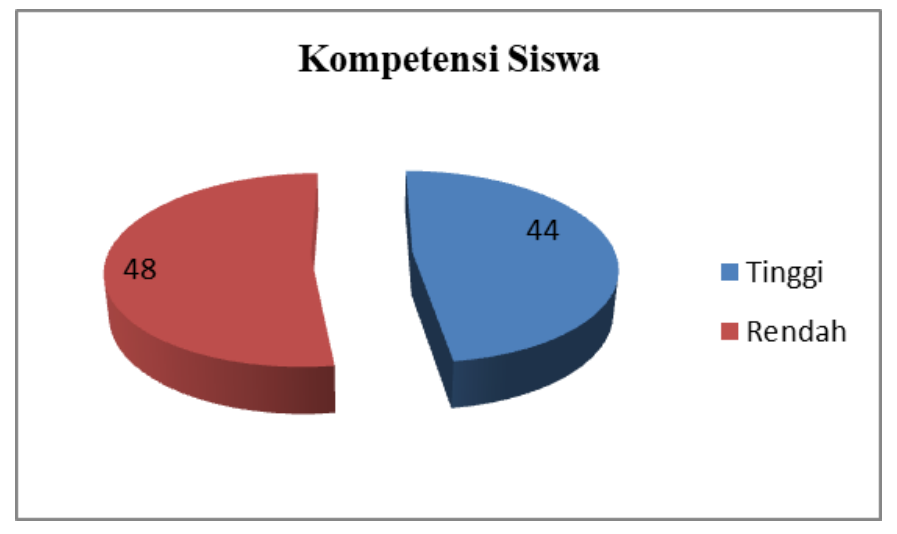

Gambar 1. Gambar Kompetensi Siswa

\section{Peran Serta BKK}

Berdasarkan hasil penelitian diketahui bahwa peran serta BKK berada pada kategori aktif sebanyak 48 siswa $(52,17 \%)$, dan berada pada kategori kurang aktif sebanyak 44 siswa $(47,83 \%)$. Dengan demikian dapat disimpulkan bahwa kecenderungan peran serta BKK kelas XI Jurusan Teknik Kendaraan Ringan SMK se-Kabupaten Bantul berada pada kategori aktif sebanyak 48 siswa $(52,17 \%)$. Adapun penggambarannya dapat digambarkan pada gambar di bawah ini.

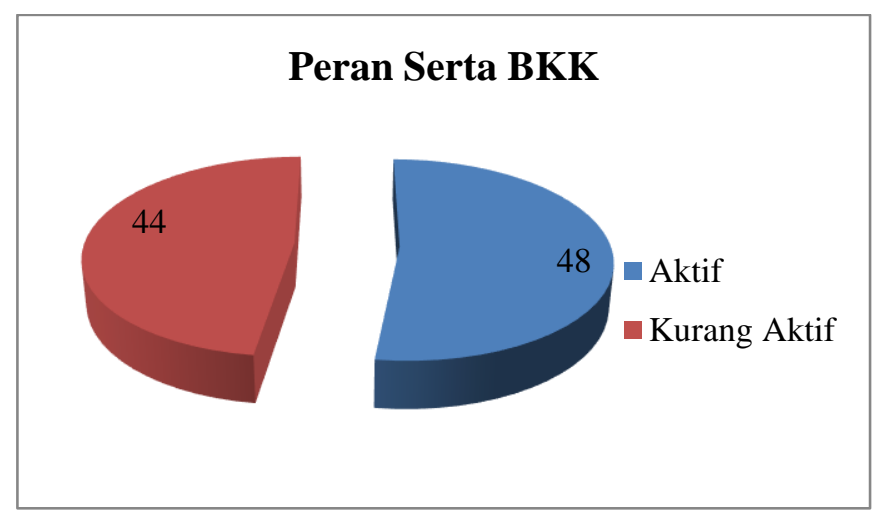

Gambar 2. Peran Serta BKK 


\section{Motivasi Kerja di Bidang Otomotif}

Berdasarkan hasil penelitian diketahui bahwa motivasi kerja di bidang otomotif berada pada kategori tinggi sebanyak 47 siswa $(51,09 \%)$, dan berada pada kategori rendah sebanyak 45 siswa $(48,91 \%)$. Dengan demikian dapat disimpulkan bahwa kecenderungan motivasi kerja di bidang otomotif kelas XI Jurusan Teknik Kendaraan Ringan SMK se-Kabupaten Bantul berada pada kategori tinggi sebanyak 47 siswa (51,09\%). Adapun penggambarannya dapat digambarkan pada gambar di bawah ini.

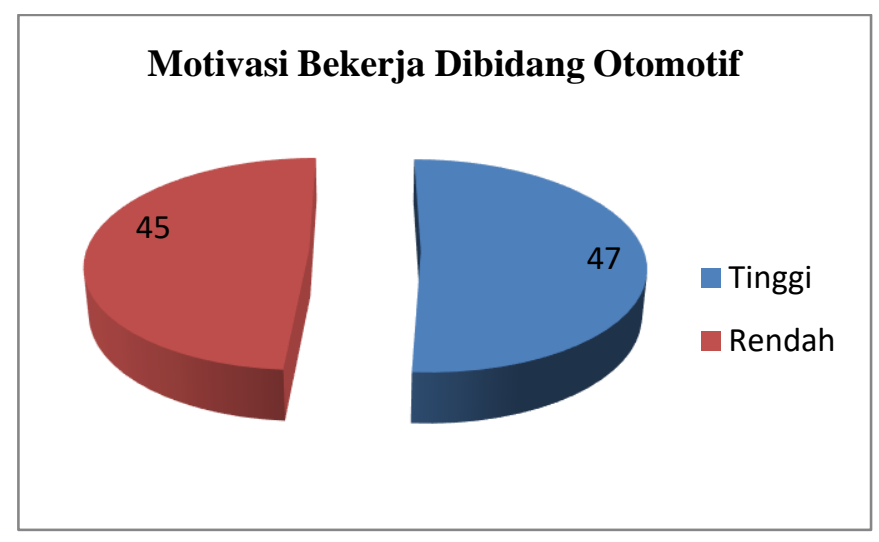

Gambar 3. Gambar Mtivasi Kerja di Bidang Otomotif

\section{Pengujian Hipotesis}

Hasil analisis data diketahui bahwa nilai $t_{\text {hitung }}$ sebesar 6,209 dengan nilai signifikansi sebesar 0,000. Kemudian nilai thitung dibandingkan dengan nilai tabel pada taraf signifikansi 5\%, sehingga diperoleh $t_{\text {tabel }}$ sebesar 1,973. Hal ini menunjukkan bahwa nilai $t_{\text {hitung }}$ lebih besar dari pada $t_{\text {tabel }}(6,209>1,973)$. Apabila dibandingkan dengan nilai signifikansi sebesar 0,000 lebih kecil dari signifikansi $0,05(0,000<0,05)$, maka Ha dalam penelitian ini dinyatakan diterima. Ada perbedaan motivasi untuk bekerja di bidang otomotif antara siswa yang memiliki kompetensi tinggi dan siswa yang memiliki kompetensi rendah.

Hasil analisis data diketahui bahwa nilai $t_{\text {hitung }}$ sebesar 6,510 dengan nilai signifikansi sebesar 0,006. Kemudian nilai $t_{\text {hitung }}$ dibandingkan dengan nilai $t_{\text {tabel }}$ pada taraf signifikansi 5\%, sehingga diperoleh $t_{\text {tabel }}$ sebesar 1,973. Hal ini menunjukkan bahwa nilai $t_{\text {hitung }}$ lebih besar dari pada $t_{\text {tabel }}(6,510>1,973)$. Apabila dibandingkan dengan nilai signifikansi sebesar 0,006 lebih kecil dari signifikansi $0,05(0,006<0,05)$, maka Ha dalam penelitian ini dinyatakan diterima. Ada perbedaan motivasi untuk bekerja di bidang otomotif pada siswa yang peran serta BKKnya aktif dan siswa yang peran serta BKKnya kurang aktif untuk bekerja di bidang otomotif. 


\section{Pembahasan}

\section{Pengaruh Kompetensi Siswa Terhadap Motivasi Untuk Bekerja Di Bidang Otomotif Siswa Kelas XI Jurusan Teknik Kendaraan Ringan SMK se-Kabupaten Bantul}

Berdasarkan hasil analisis data diketahui bahwa ada pengaruh kompetensi siswa terhadap motivasi untuk bekerja di bidang otomotif siswa kelas XI Jurusan Teknik Kendaraan Ringan SMK se-Kabupaten Bantul. Hal ini ditunjukkan dari nilai thitung lebih besar dari nilai $t_{\text {tabel }}$ $(6,209>1,973)$, nilai signifikansi lebih kecil dari $0,05(0,000<0,05)$. Hal ini dapat diartikan bahwa siswa dengan kompetensi tinggi mempunyai motivasi untuk bekerja di bidang otomotif lebih tinggi dari pada siswa yang mempunyai kompetensi rendah.

Motivasi memasuki dunia kerja adalah suatu yang menimbulkan semangat atau dorongan individu untuk memasuki dunia kerja, baik berasal dari dalam diri sendiri maupun dari luar dirinya. Menurut Hamzah B. Uno (2010: 10) Motivasi timbul karena adanya keinginan untuk melakukan kegiatan, adanya dorongan dan kebutuhan melakukan kegiatan, adanya harapan dan cita-cita, adanya penghormatan atas diri, adanya lingkungan yang baik dan adanya kegiatan yang menarik.

Motivasi memasuki dunia kerja timbul karena adanya minat dan keinginan dari dalam diri peserta didik. Minat dan keinginan ini berupa harapan-harapan masa depan yang lebih baik. Seorang peserta didik tentu memiliki cita-cita akan sebuah pekerjaan setelah lulus dari SMK. Sesuai dengan psikologi perkembangan remaja, menurut Ali dan Asrori (2008: 94) seseorang yang telah memasuki remaja akhir, dalam hal ini peserta didik akan cenderung memilih karier tertentu meskipun dalam memilih karier tersebut masih mengalami kesulitan. Hal ini wajar karena pada orang dewasa pun sering kali masih terjadi perubahan orientasi karier dan kembali berusaha menyesuaikan diri dengan karier baru.

Selain itu, dorongan terbesar untuk bekerja sesuai keinginan juga dilandasi adanya kompetensi seseorang (Ching, Siswanto, \& Febriana, 2019). Kompetensi menurut Rosyada (2004: 48) adalah pengetahuan keterampilan dan nilai-nilai yang direfleksikan dalam kebiasaan berpikir dan bertindak. Kebiasaan-kebiasaan harus mampu dilaksanakan secara konsisten dan terus menerus, serta mampu untuk melakukan penyesuaian-penyesuaian dengan berbagai perubahan yang terjadi dalam kehidupan, baik profesi, keahlian, maupun lainnya.

Kompetensi meliputi task skill, task management skill, contingensi management skill, job or role environment skill, dan transfer skill (Depdiknas, 2004: 8-9). Kompetensi diartikan sebagai kebiasaan berpikir dan bertindak secara konsisten dan terus menerus dapat memungkinkan seseorang menjadi kompeten, dalam arti memiliki pengetahuan, keterampilan, 
68 Muhammad Afifi

dan nilai-nilai dasar untuk melakukan sesuatu. Dengan demikian terdapat hubungan antara tugas-tugas yang dipelajari peserta didik di sekolah dengan kemampuan yang diperlukan oleh dunia kerja (Trianto, 2010: 15).

Penilaian untuk mengetahui siswa SMK kompeten atau tidak dilakukan melalui ujian kompetensi keahlian (UKK). Pemerintah akan memfasilitasi SMK yang telah terlisensi sebagai LSP-P1 atau memenuhi kriteria yang ditetapkan BNSP (Badan Nasional Sertifikasi Profesi) sebagai Tempat Uji Kompetensi (TUK). Kompetensi yang diujikan merujuk pada kualifikasi jenjang 2 atau 3 Kerangka Kualitikasi Nasional Indonesia (KKNI) yaitu pada jabatan operator. Hasil ujian kompetensi keahlian tersebut nantinya skill passport sebagai bukti siswa tersebut telah kompeten pada kualifikasi lulusan SMK, dan diharapkan dapat dengan mudah mendapat pekerjaan sehingga menekan angka pengangguran. Hal ini sejalan dengan teori Slamet (2002: 54) ciri utama kompetensi adalah "kemampuan mengerjakan sesuatu". Oleh karenanya, tingkat kemampuan mengerjakan sesuatu sering dipergunakan sebagai pengukur tingkat kualitas tamatan.

Adanya kompetensi siswa SMK tersebut sangat penting karena siswa yang memiliki kompetensi tinggi akan memunculkan motivasi atau dorongan untuk bekerja di bidang otomotif sesuai dengan jurusan yang diambil. Hal ini menjadi penting mengingat, Sekolah Menengah Kejuruan (SMK) merupakan lembaga pendidikan yang mencetak sumber daya manusia sebagai tenaga kerja yang profesional. Tenaga kerja yang dibutuhkan adalah sumber daya manusia yang memiliki kompetensi sesuai dengan bidang pekerjaannya, memiliki daya adaptasi dan daya saing yang tinggi sesuai dengan kondisi dan kebutuhan dunia kerja, yaitu tenaga kerja yang mempunyai keterampilan dan keahlian yang profesional dan produktif.

\section{Pengaruh Peran Serta BKK Terhadap Motivasi Untuk Bekerja Di Bidang Otomotif Siswa Kelas XI Jurusan Teknik Kendaraan Ringan SMK se-Kabupaten Bantul}

Berdasarkan hasil analisis data diketahui bahwa ada pengaruh kompetensi siswa terhadap motivasi untuk bekerja di bidang otomotif siswa kelas XI Jurusan Teknik Kendaraan Ringan SMK se-Kabupaten Bantul. Hal ini ditunjukkan dari nilai thitung lebih besar dari nilai $t_{\text {tabel }}$ $(6,510>1,973)$, nilai signifikansi lebih kecil dari $0,05(0,006<0,05)$. Hal ini dapat diartikan bahwa sekolah yang peran serta BKKnya aktif mempunyai siswa dengan motivasi untuk bekerja di bidang otomotif lebih tinggi dari pada siswa dari sekolah yang peran serta BKKnya kurang aktif.

Bursa Kerja Khusus merupakan satu rangkaian dari program sekolah yang tidak terdapat di dalam kurikulum sekolah. Mekanisme kerja BKK secara garis besar menawarkan lulusan ke dunia usaha atau dunia industri berdasarkan data lulusan menurut program studi. Sedangkan 
dari pihak dunia usaha atau dunia industri menawarkan lowongan pekerjaan pada BKK. BKK dalam menjalankan program kegiatannya bekerjasama dengan kantor instansi yang bertanggung jawab di bidang ketenagakerjaan baik itu propinsi maupun kabupaten/ kota seperti, Perusahaan Penempatan Tenaga Kerja Indonesia Swasta (PPTKIS), Lembaga Pelayanan Penempatan Tenaga Kerja Swasta (LPPS) dan instansi-instansi terkait.

Bursa Kerja Khusus menurut Departemen Tenaga Kerja dan Transmigrasi RI, Dirjen Binapenta (2010: 3), memberikan rumusan bahwa: "BKK adalah suatu bursa kerja yang berada di satuan pendidikan menengah, pendidikan tinggi dan lembaga-lembaga pelatihan kerja lainnya yang mengadakan kegiatan pelayanan antar kerja bagi siswa lulusannya, memberikan informasi pasar kerja, pendaftaran pencari keja, memberi penyuluhan dan bimbingan serta penyaluran dan penempatan tenaga kerja" Fungsi dari BKK adalah mempertemukan antara pencari kerja dengan pengguna lulusan. Dari fungsi tersebut dapat dilihat bahwa peran BKK sangat penting yaitu sebagai mediator antara pengguna tenaga kerja dan tenaga kerja (lulusan) untuk mendapatkan pekerjaan. Untuk mewujudkan tujuan BKK dan menjalankan fungsifungsinya secara optimal maka harus dikelola secara profesioanal oleh sekolah.

Kinerja BKK yang profesional akan memberikan dampak yang positif bagi sekolah dalam memenuhi permintaan tenaga kerja yang datang dari dunia usaha/dunia industri sesuai dengan persyaratan yang dibutuhkan. BKK merupakan ujung tombak keberhasilan sekolah dalam menyalurkan siswa ke dunia kerja. Jika BKK mampu menjalankan fungsi-fungsi BKK dengan baik, maka motivasi siswa untuk bekerja di bidang otomotif akan meningkat karena banyak referensi yang menjadi harapan untuk bekerja sesuai dengan jurusannya yaitu otomotif.

\section{SIMPULAN}

Berdasarkan hasil analisis data dan pembahasan maka dapat ditarik kesimpulan bahwa:

1. Siswa dengan kompetensi tinggi mempunyai motivasi untuk bekerja di bidang otomotif lebih tinggi dari pada siswa yang mempunyai kompetensi rendah yang ditunjukkan dari nilai thitung lebih besar dari nilai $t_{\text {tabel }}(6,209>1,973)$, nilai signifikansi lebih kecil dari 0,05 $(0,000<0,05)$. Hasil temuan tersebut menunjukkan jika ada pengaruh kompetensi siswa terhadap motivasi untuk bekerja di bidang otomotif siswa kelas XI Jurusan Teknik Kendaraan Ringan SMK se-Kabupaten Bantul.

2. Sekolah yang peran serta BKKnya aktif mempunyai siswa dengan motivasi untuk bekerja di bidang otomotif lebih tinggi dari pada siswa yang peran serta BKKnya kurang aktif yang ditunjukkan dari nilai $t_{\text {hitung }}$ lebih besar dari nilai $t_{\text {tabel }}(6,510>1,973)$, nilai signifikansi lebih kecil dari $0,05(0,006<0,05)$. Hasil temuan tersebut menunjukkan jika ada pengaruh peran 
70 Muhammad Afifi

serta BKK terhadap motivasi untuk bekerja di bidang otomotif siswa kelas XI Jurusan

Teknik Kendaraan Ringan SMK se-Kabupaten Bantul.

\section{DAFTAR PUSTAKA}

Akbar Suryanti. (2016). Media Pembelajaran Teknik Kendaraan Ringan Untuk Siswa Smk Menggunakan Adobe Flash (Studi Kasus: Smk Muhammadiyah I Bambanglipuro). Jurnal Fakultas Teknik.

Ali, Mohammad dan Asrori, Mohammad. (2008). Psikologi Remaja Perkembangan Peserta Didik. Jakarta: PT.Bumi Aksara.

Ching, S. J., Siswanto, I., \& Febriana, R. (2019). Psychological Capital, Social Support, and Career Capital of Indonesian Students in Taiwan. Jurnal Pendidikan Teknologi dan Kejuruan, 25(1), 1-9.

Depdiknas. (2004). Standar Kompetensi Guru. Jakarta: Depdiknas.

Depnakertrans RI. (2004). Keputusan Direktur Jenderal Pembinaan dan Penempatan Tenaga Kerja Dalam Negeri No. KEP131/DPPTKDN/XI/2004, tentang Petunjuk Teknis Bursa Kerja Khusus.

Haryana, K., Tawardjono, Us, \& Tafakur, T. (2018). HUBUNGAN KOMPETENSI MENCARI SUMBER BELAJAR DENGAN PRESTASI BELAJAR MAHASISWA JURUSAN PENDIDIKAN TEKNIK OTOMOTIF FT UNY. Jurnal Pendidikan Vokasi Otomotif, 1(1), 12-25.

Peraturan Pemerintah Nomor 29 Tahun 1990 tentang Pendidikan Menengah Kejuruan.

Rosyada, Dede. (2004). Paradigma Pendidikan Demokratis. Jakarta: Kencana.

Slamet, PH. (2002). Pendidikan Kecakapan Hidup, Kosep Dasar. Jurnal Pendidikan dan Kebudayaan, No.037, th. Ke-8, Juli 2002.

Trianto. (2010). Mengembangkan Model Pembelajaran Tematik. Jakarta: PT Prestasi Pustaka. Umar, H. (2005). Metode Penelitian. Jakarta: Salemba Empat.

Undang-Undang Sistem Pendidikan Nasional Nomor 20 Tahun 2003 tentang Pendidikan Kejuruan.

Uno, Hamzah B. (2010). Teori Motivasi dan Pengukurannya. Jakarta: PT Bumi Aksara. 